\title{
Hospital Site Selection in Iskandar Malaysia using GIS-Multi Criteria Analysis

\author{
Maqsood Rezayee
}

\begin{abstract}
Hospital is one of the most important and beneficial public services in the world, therefore, these facilities should be located in a rational manner. Increasing the population of countries particularly developing countries and remote areas leads to the demand for new public health facilities and hospitals. No matter who provides the healthcare facilities, the most important issue is where to locate a new hospital to provide, both facility location and attractiveness. Hospital proper site selection has a vital role in hospital construction and management. From the aspect of the government and healthcare organization, appropriate hospital site selection will help optimize the allocation of medical resources, matching the provision of health care with the social and economic demands. From the aspect of the investors and operators of the hospital, optimum hospital site selection will definitely be cost-saving on capital strategy. On the other hand, establishing a hospital in urban districts has its own positive and negative consequences. The positive impacts of establishing a hospital in an area are that it increases property value in the neighboring periphery as well as improving healthrelated accessibility for the residents of that urban district. The negative impacts of establishing a hospital in an area are negative side-effects such as environmental contamination and inducing new waves of traffic flow. Then, the adjacent community is impacted by forms of increased traffic flow, increased emergency vehicle usage in residential areas. Therefore, in hospital site selection should be tried to reduce the negative impacts. Then, main aim of this paper is to select a site for the building of a new hospital in Iskandar Malaysia using GIS-based Multi-Criteria Analysis (MCA) with consideration of various factor criteria, and constraint criteria in order to balance the medical resource there.
\end{abstract}

Keywords: Hospital, Site Selection, GIS, Multi-Criteria Analysis, Iskandar Malaysia.

\section{INTRODUCTION}

Hospital is one of the most important and beneficial public services in the world, therefore, these facilities should be located in a rational manner [1]. Increasing the population of countries particularly developing countries and remote areas leads to the demand for new public health facilities and hospitals [2]. By economic growth, many private-public health facilities are starting services but mostly serving for the upper class and upper-middle class of the people, for lower-income and lower middle class the health facilities are limited particularly in remote and rural areas [3-5].

Revised Manuscript Received on February 07, 2020.

* Correspondence Author

Maqsood Rezayee, Department of Urban and Regional Planning, Faculty of Built Environment and Surveying, Universiti Teknologi Malaysia, Skudai, 81310 Johor Bahru, Johor, Malaysia. Email:mqsoodrezay@yahoo.com

(C) The Authors. Published by Blue Eyes Intelligence Engineering and Sciences Publication (BEIESP). This is an open access article under the CC BY-NC-ND license (http://creativecommons.org/licenses/by-nc-nd/4.0/)
The above situation amplifies the need for new hospitals to be set up by the governments, profit or nonprofit health organizations, charities, insurance companies or even religious orders for the poorer sections of the society who cannot spend a huge amount in health care [1,2]. No matter who provides the healthcare facilities, the most important issue is where to locate a new hospital to provide, both facility location and attractiveness [1]

Hospital proper site selection has a vital role in hospital construction and management [2-4]. From the aspect of the government and healthcare organization, appropriate hospital site selection will help optimize the allocation of medical resources, matching the provision of health care with the social and economic demands, coordinating the urban and rural health service development, and easing social contradictions [5-7]. From aspect of the citizen, proper hospital site selection will improve access to the healthcare, reduce the time of rescue, satisfy people's medical needs as well as enhance the quality of life [1-3]. From the aspect of the investors and operators of the hospital, optimum hospital site selection will definitely be cost-saving on capital strategy [1-3].

Establishing a hospital in urban districts has its own positive and negative consequences. Positive impacts of establishing a hospital in an area are that it increases property value in the neighboring periphery as well as improving health-related accessibility for the residents of that urban district $[1,7,8]$. The negative impacts of establishing a hospital in an area are negative side-effects such as environmental contamination and inducing new waves of traffic flow appearing on the network serving the district, then, the adjacent community is impacted by forms of increased traffic flow, increased emergency vehicle usage in residential areas [1, 8]. Therefore, in hospital site selection should be tried to reduce the negative impacts. Therefore, main aim of this paper is to select a site for the building of a new hospital in Iskandar Malaysia using GISbased Multi-Criteria Analysis (MCA). Considering various factor criteria, and constraint criteria in order to balance the medical resource there.

\section{STUDY AREA}

The study area for this project is Iskandar Malaysia. Iskandar Malaysia knew as Malaysia's economic growth corridor which covers 2217 sq. km (12\% of Johor state) [912]. Iskandar Malaysia, previously known as the South Johor Economic Region (SJER) and the Iskandar Development Region (IDR), Southern tip of Peninsular Malaysia [9,10]. The region was established in 2006 as one of the catalyst development corridors to encourage the growth of the Malaysian economy into the first quarter of the 21 century [ 9,12]. Fig. I shows Iskandar Malaysia.

Blue Eyes Intelligence Engineering 


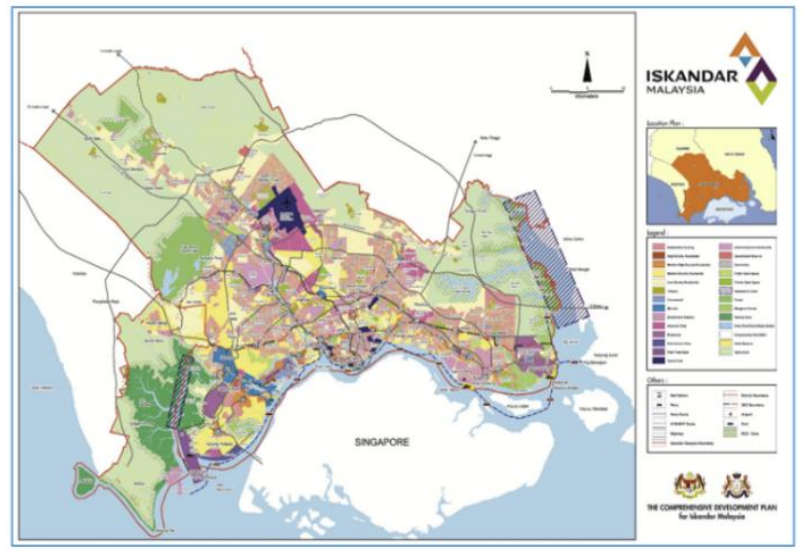

Fig. 1 Iskandar Malaysia. Source: [4]

There is different type of hospital in Malaysia, Table. I show different types of hospitals in Malaysia

Table. I: Different types of hospitals in Malaysia

\begin{tabular}{|c|c|c|c|c|c|c|}
\hline Category & \multicolumn{6}{|c|}{ Category A } \\
\hline Population & $>400000$ & $\begin{array}{l}300000- \\
400000\end{array}$ & $\begin{array}{l}200000- \\
300000\end{array}$ & $\begin{array}{l}100000- \\
200000\end{array}$ & $\begin{array}{l}45000- \\
100000\end{array}$ & $\begin{array}{l}k_{4} \\
45000 \\
\end{array}$ \\
\hline $\begin{array}{l}\text { Number } \\
\text { of bed }\end{array}$ & $>800$ & $600-800$ & $400-600$ & $200-400$ & $90-200$ & $k 90$ \\
\hline $\begin{array}{l}\text { Minimum } \\
\text { Area } \\
\text { Hectare }\end{array}$ & 12 & 10 & $\beta$ & 6 & 4 & 3 \\
\hline Category & \multicolumn{6}{|c|}{ Category B } \\
\hline Population & $>300000$ & $\begin{array}{l}200000- \\
300000\end{array}$ & $\begin{array}{l}100000- \\
2000000\end{array}$ & $\begin{array}{l}50000- \\
100000\end{array}$ & $\begin{array}{l}30000- \\
50000\end{array}$ & $\begin{array}{l} \\
30000\end{array}$ \\
\hline $\begin{array}{l}\text { Number } \\
\text { of bed }\end{array}$ & $>600$ & $400-600$ & $200-400$ & $100-200$ & $60-100$ & $k 60$ \\
\hline $\begin{array}{l}\text { Minimum } \\
\text { Area } \\
\text { Hectare }\end{array}$ & 12 & 12 & 8 & $\beta$ & 4 & 4 \\
\hline
\end{tabular}

In this study the type B hospital for 200000-300000 Population with 400- 600 beds considered, then the minimum area for this kind of hospital must be more than 12 Hectares (120000 m2).

\section{METHODOLOGY}

The methodologies and analyses which are using for the site selection in this study are GIS-based Multi-criteria analysis (MCA) and weighting of criteria. MCA is a procedure which includes many criteria, that are essential to be evaluated in decision-making [2]. MCA includes two essential parts, factor criteria and constraint criteria [2]. Each of the criteria is appeared as a map layer. Factor maps are shows as spatial distributions to display the opportunity criteria and the quality of achieving an objective. Constraint maps are limitations or restrictions which prevent particular elements to be taken into account the analysis [1,2].

The weight for each criterion was given according to the factor's importance. The hospital site selection criteria were identified through reviewing the literature following that, the criteria divided into factor criteria and constraint criteria. Some factor criteria have been considered such as population, the distance between existing hospital, distance from the main road, distance from the ferry terminal, distance from ferry route and distance from the river. Following that the weight from 1 to 3 assigned for each factor criteria, according to the importance of factor 3 is given for the factor which is more important and the 1 is given for the factor which is less important. In addition to factor criteria, some constraint criteria also have been considered such as railway, highway, university area and greenbelt areas.

\section{FACTOR CRITERIA}

According to Iskandar Malaysia's data, following are considered as the Factor criteria for this research.

1. Existing hospital. This is an important criterion for the rational location of new hospital, keeping the distance from existing hospital is the fair contribution of health care facilities and will balance the medical services for residents of Iskandar Malaysia. According to [1-3] at least 500 meters' distance must be considered from existing hospital.

2. Residential area: it is better to locate hospital near to residential areas in order to ensure the accessibility for residents. The residential areas with high population have a higher priority than the areas with low population. Then in this research, the area with a high population gets higher priority.

3. Main road: The hospital should be located near the main roads, because of better accessibility. On the other hand, when the vehicles are passing the road, their noises negatively impact on the patients. Therefore, a quiet distance of 100 meters must be set, outside the quiet zone, the nearer is the better $[8,9]$.

4. River: Because the river may be polluted because of connection to the drainage system. Thus, at least the new hospital must have 300 meters' distance from the river [2]. Outside the buffer zone, the further is the better.

5. Ferry route: According to data there are many routes for the ferry in Iskandar Malaysia. Because ferry is the mode of public transport which can ensure accessibility for the hospital. Thus, it is better to locate hospital near to ferry route and ferry terminal with quiet distance of 300 meters. Outside the quiet zone the nearer the better.

Table. II shows the specific buffer requirements for factor criteria.

Table. II: Specific buffer requirements for factor criteria. Adapted from $[1,2,3,7,8]$

\begin{tabular}{|l|l|}
\hline Factor & Setting \\
\hline $\begin{array}{l}\text { Existing } \\
\text { hospital }\end{array}$ & $\begin{array}{l}\text { further from existing hospital better but at least } \\
>500 \text { meters }\end{array}$ \\
\hline $\begin{array}{l}\text { population } \\
\text { of area }\end{array}$ & $\begin{array}{l}\text { the resident with high population has high } \\
\text { priority. }\end{array}$ \\
\hline Main road & $\begin{array}{l}\text { Near to the main road is better but by keeping at } \\
\text { least } 100 \text { meters' distance quiet site. }\end{array}$ \\
\hline River & $\begin{array}{l}\text { The further away from the river is better but at } \\
\text { least }>300 \text { meters }\end{array}$ \\
\hline Ferry route & $\begin{array}{l}\text { Near to ferry route is better but by keeping at } \\
\text { least } 300 \text { meters' distance quiet site. }\end{array}$ \\
\hline $\begin{array}{l}\text { Ferry } \\
\text { terminal }\end{array}$ & $\begin{array}{l}\text { Near to ferry terminal is better but by keeping at } \\
\text { least } 300 \text { meters' distance quiet site. }\end{array}$ \\
\hline
\end{tabular}

\section{A. Data Process of Factor Criteria}

Start performing the multiple ring buffers according to factor criteria's distance criterion (Table. II). Fig. II. Shows the implemented multiple ring buffers for Factor criteria.

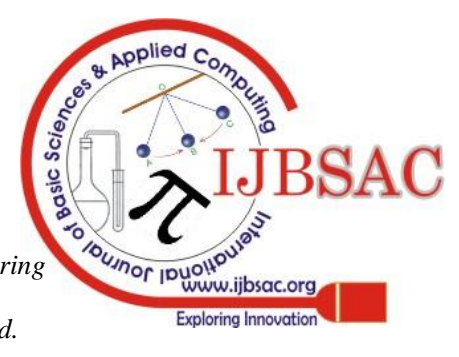




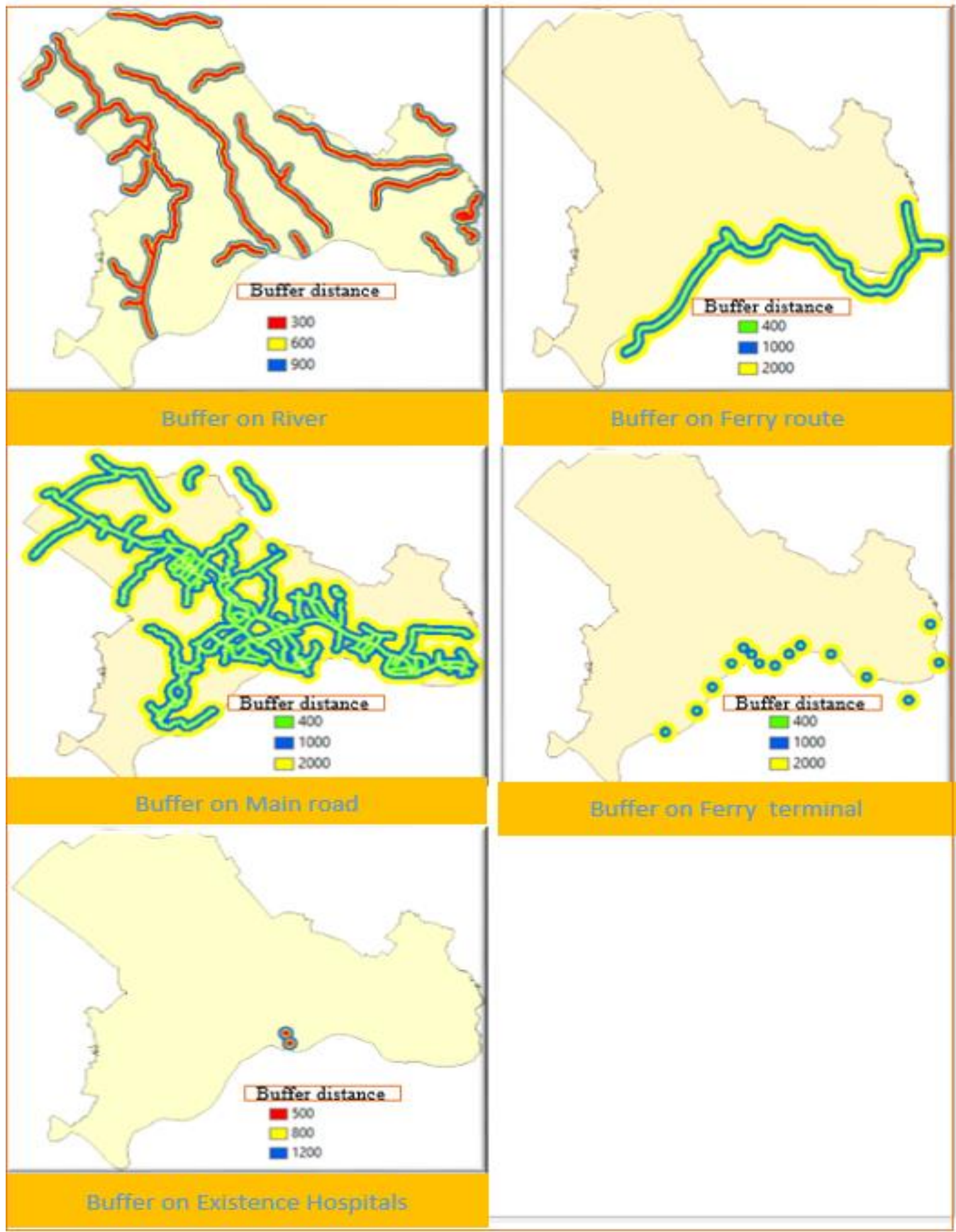

Fig. 2 Implemented multiple ring buffers for Factor criteria

The suitability weight is using in this research to determine the importance of each factor. The ranking method has been used to define the weight of each factor. The weight assigned between 1 to 3 , which 3 is most important criterion and 1 is less important criterion. All ranking weight converted to a numerical decimal number by finding the importance percentage of each factor. (Table II).

1. Main road: for the main road the weight assigned 3 because the accessibility of the hospital is most important and the main road leads the accessibility to hospital.

2. Ferry route: for ferry route the weight assigned 1 because it can help access into hospital, but not the similar of the main road.

3. Ferry terminal: for ferry terminal the weight assigned 1.

4. Population: for population, the weight assigned 3, because aim of the site selection of hospital in this research is to balance the medical services for the population. Theodore, it is important to be located hospital near to residential area to ensure accessibility.

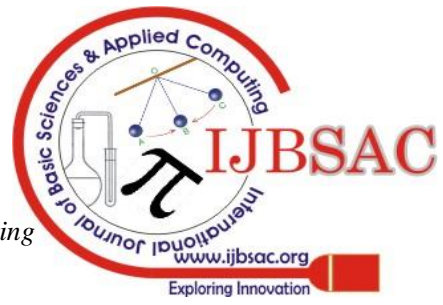


5. River: for the river the weight assigned 2.

6. Existing hospital. for keeping the distance between existing hospitals and new hospital, the weight assigned 3. Locating the new hospital near to existing hospitals is improper and insufficient. Table III. shows the assigned weight for each factor criteria.

Table. III: Suitability score. Adapted from $[1,2,3,7,8]$

\begin{tabular}{|c|c|c|c|c|c|c|}
\hline \multirow{4}{*}{$\begin{array}{l}\text { Layer } \\
\text { name }\end{array}$} & \multicolumn{3}{|c|}{ Suitability Score } & \multirow{2}{*}{\begin{tabular}{|c|}
$\begin{array}{c}\text { Assigned } \\
\text { weight }\end{array}$ \\
\end{tabular}} & \multirow{2}{*}{$\begin{array}{c}\% \\
\text { Weight }\end{array}$} & \multirow{2}{*}{ Multiplier } \\
\hline & Low & Medium & High & & & \\
\hline & 1 & 2 & 3 & & & \\
\hline & \multicolumn{3}{|c|}{ Accessibility } & & & \\
\hline Main Road & $\begin{array}{c}>1000 \\
M\end{array}$ & $\begin{array}{c}400- \\
1000 \mathrm{M}\end{array}$ & $\begin{array}{c}100-400 \\
M\end{array}$ & 3 & 23.1 & 0.23 \\
\hline ferry route & $\begin{array}{c}>1000 \\
M\end{array}$ & $\begin{array}{c}400- \\
1000 \mathrm{M}\end{array}$ & $\begin{array}{c}300-400 \\
M\end{array}$ & 1 & 7.7 & 0.08 \\
\hline \multirow[t]{2}{*}{$\begin{array}{c}\text { ferry } \\
\text { Terminal } \\
\end{array}$} & $\begin{array}{c}>1000 \\
M\end{array}$ & $\begin{array}{c}400- \\
1000 \mathrm{M}\end{array}$ & $\begin{array}{c}300-400 \\
M\end{array}$ & 1 & 7.7 & 0.08 \\
\hline & \multicolumn{3}{|c|}{ population } & & & \\
\hline \multirow[t]{2}{*}{$\begin{array}{l}\text { Residential } \\
\text { population }\end{array}$} & k100000 & $\begin{array}{l}100000- \\
200000\end{array}$ & $>200000$ & 3 & 23.1 & 0.23 \\
\hline & \multicolumn{3}{|c|}{ River } & & & \\
\hline \multirow[t]{2}{*}{ River } & $\begin{array}{c}300- \\
600 \mathrm{M}\end{array}$ & $\begin{array}{c}600- \\
900 \mathrm{M}\end{array}$ & $>900 \mathrm{M}$ & 2 & 15.4 & 0.15 \\
\hline & \multicolumn{3}{|c|}{ Existing hospital } & & & \\
\hline $\begin{array}{l}\text { Existing } \\
\text { hospital }\end{array}$ & $\begin{array}{c}500- \\
800 \mathrm{M}\end{array}$ & $\begin{array}{c}800- \\
1200 \mathrm{M}\end{array}$ & $\begin{array}{c}> \\
1200 \mathrm{M}\end{array}$ & 3 & 23.1 & 0.23 \\
\hline Total & & & & 13 & 100 & 1 \\
\hline
\end{tabular}

\section{B. Data Conversion}

All vector data which is involved in factor criteria, after implementing the distant buffer and given the value converted to raster data. Fig. III. Factor Map of Factor Criteria.

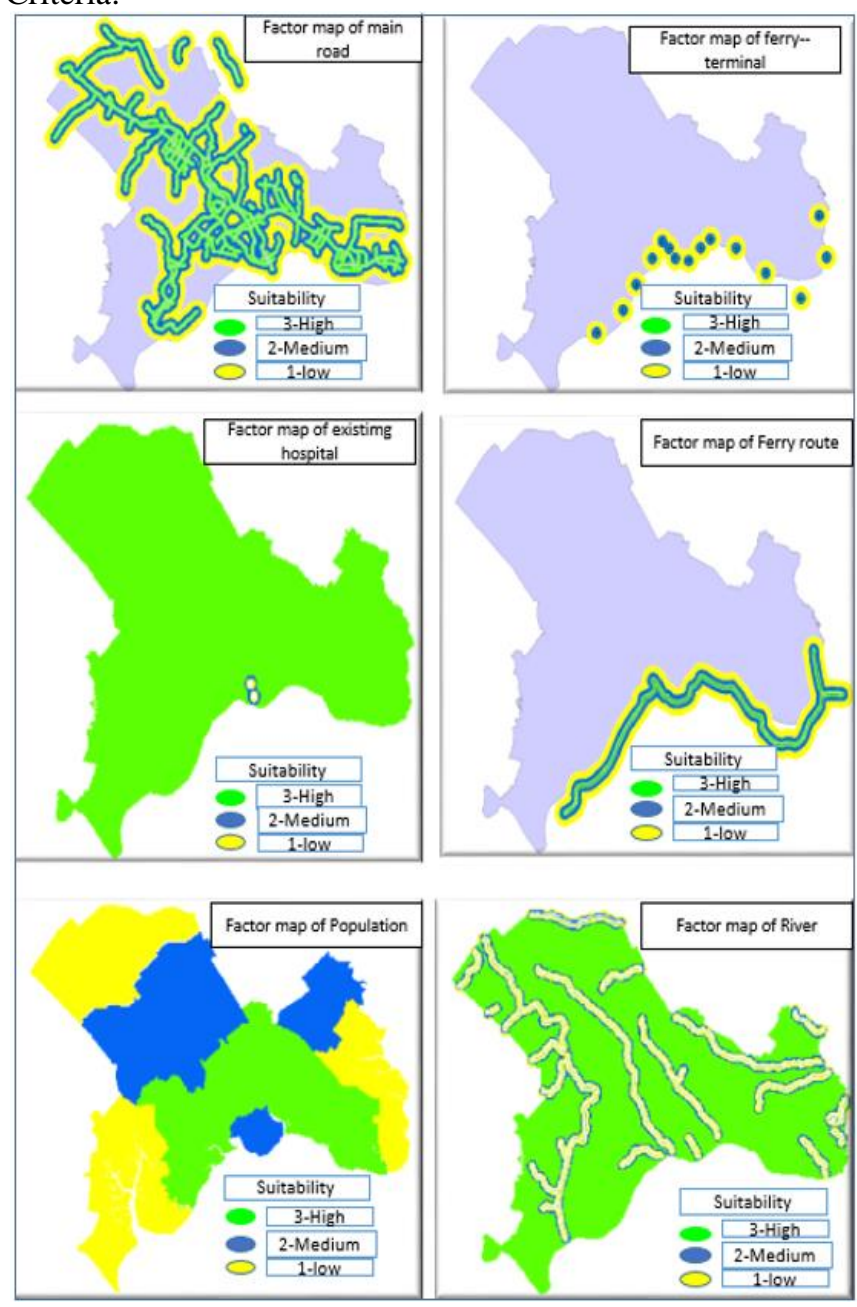

Fig. 3 Factor Map of all Factor Criteria

\section{CONSTRAINT CRITERIA}

According to Iskandar Malaysia's data, the following are the constraint criteria for this study.

1. University area: because the universities have their own hospitals or clinics. Then, it is unnecessary to build new hospitals there.

2. Greenbelt areas: in the greenbelt area, the residents come together and discusses the different thing and have a fun time together. Greenbelt area is a noisy area; it is not proper to build hospitals inside the greenbelt areas. On the other hand, hospital has an impact on greenbelt areas, which will pollute the greenbelt areas. Therefore, it is not proper to locate the hospital inside the greenbelt areas.

3. Highway: according to data there are many highways in Iskandar Malaysia. When the vehicles are passing the highway the noise from motor vehicles has a negative impact on the patients in the hospital. The residential area usually located far from highway and land-use around the highway is usually open area. There is no priority to build new hospital in contrast with other areas which have higher priority. At least 500 meters' buffer zone must be considered from highway in order to keep quiet sites for the new hospital.

4. Railway: when the trains crossing the way their noisy sound will disturb the Patients. Then the hospital at least must be located 1000 meters far from the railway [2].

5. Rail station: Since the patients will be disturbed by noisy sound of trains when coming to stations and start moving from station. Thus, the hospital must be located at least with 1000 meters' quiet distance from rail station [2].

6. Ring road: There is 16 ring road in Iskandar Malaysia. In ring road vehicle is moving speedy and generates noisy sound. Then around the ring road areas are not proper sites for the hospital. At least 500 meters quiet distant is essential.

7. Vacant Land: In this research the type B hospital for 200000-300000 population with 400- 600 beds considered, then the minimum area for this kind of hospital must be more than 12 Hectares. Table. III shows constraint criteria setting.

Table IV. Constraint criteria setting. Adapted from [1, 2 , $3,7,8]$

\begin{tabular}{|l|l|}
\hline Constraint & Setting (0= forbiddance; 1=allowance) \\
\hline $\begin{array}{l}\text { University } \\
\text { areas }\end{array}$ & Inside the area is $=0$, outside the area is $=1$ \\
\hline Ring road & $\begin{array}{l}500 \text { meters buffer zone is set, inside }=0 \text {, } \\
\text { outside }=1\end{array}$ \\
\hline highway & $\begin{array}{l}500 \text { meters buffer zone is set, inside }=0, \\
\text { outside }=1\end{array}$ \\
\hline Railway & $\begin{array}{l}1000 \text { meters buffer zone is set, inside }=0, \\
\text { outside }=1\end{array}$ \\
\hline $\begin{array}{l}\text { Greenbelt } \\
\text { area }\end{array}$ & inside the greenbelt area $=0$, outside $=1$ \\
\hline Rail station & $\begin{array}{l}1000 \text { meters buffer zone is set, inside }=0, \\
\text { outside }=1\end{array}$ \\
\hline Vacant land & Inside the Vacant land areas $=1$, outside $=0$ \\
\hline
\end{tabular}

Published By:

Blue Eyes Intelligence Engineering \& Sciences Publication

(C) Copyright: All rights reserved. 


\section{A. Data Process of Constraint Criteria}

Buffering the distance for constraint criteria: the single buffers implemented according to constraint criteria's distance criterion (Table III). The buffer distance shows the constraint map for every constraint factor (Fig. IV).

Union the constraint criteria: each constraint criteria after implementing the distance buffer united with Iskandar Malaysia's boundary.

Give the value for constraint criteria: in order to determine the suitable and unsuitable area for the hospital. 1 is given for the suitable area and the 0 given for unsuitable area see (Table III).

Union all constraint criteria: all constraint factors united after given the value.

Convert to raster data all constraint criteria: all united constraint criteria converted to raster data.

Raster calculation: after conversion, all factors criteria and united of all constraint criteria the raster calculation implemented to get the result.

Reclassification: after the raster calculation the result reclassified to determine the high suitable, medium suitable and low suitable areas.

Convert to vector data the raster result data: in order to know another characteristic of the candidate sites the raster data converted to vector data.

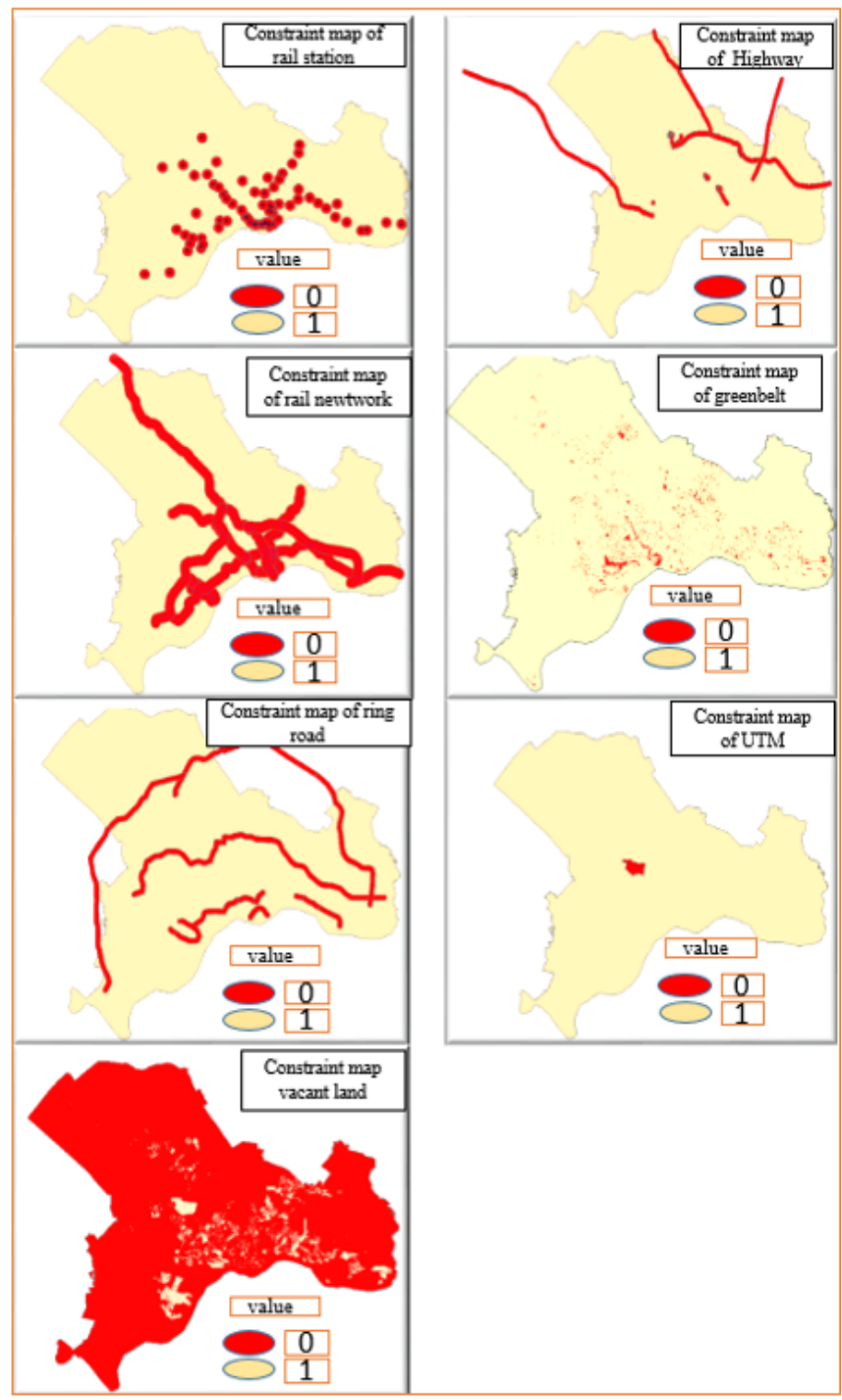

Fig. 4 Constraint map of all constraint criteria

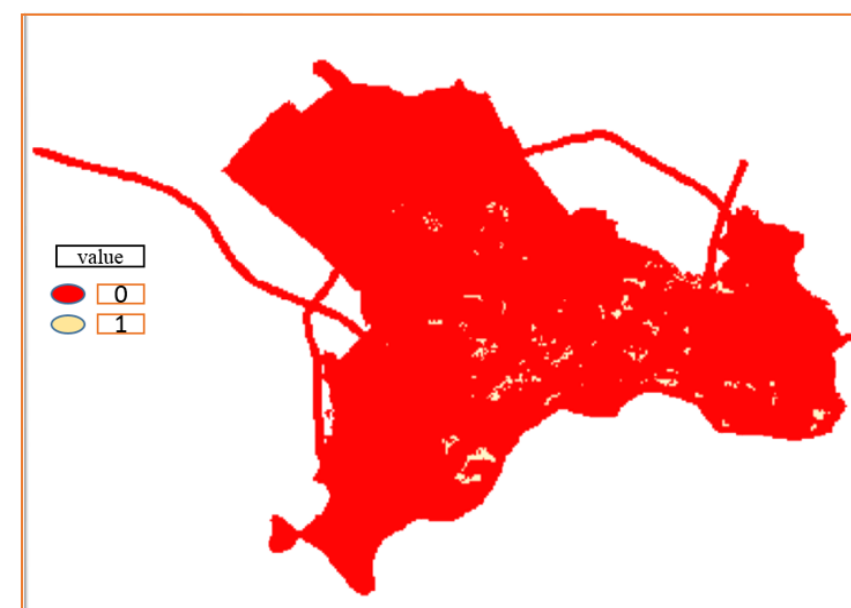

Fig. 5Constraint map of all constraint criteria after the union

\section{RASTER CALCULATION AND RESULT}

The raster calculation used to calculate the suitability of both factors criteria and constraint criteria. After the calculation, the suitable sites come up with high suitability and low suitability. The reclassification implemented to determine the areas with high suitability, medium suitability, and low suitability. Equation 1 is used for raster calculation.

$$
\mathrm{Si}=\Sigma \mathrm{Fk} * \mathrm{Xik} * \Pi \mathrm{Cic}(1)
$$

Equation 1 Raster calculation

$\mathrm{Si}=$ the suitability of location $\mathrm{i}$

$\mathrm{Fk}=$ the weight assigned for factor criterion $\mathrm{k}$. (raster data of $\mathrm{k}$ factor)

$\Sigma=$ sum of the suitability of both factors criteria and union of constraint criteria

Xik = the suitability score of location $\mathrm{i}$, on factor criterion $\mathrm{k}$ $\mathrm{Cic}=$ the suitability value of location $\mathrm{i}$, on constraint $\mathrm{c}$ $\Pi=$ the product of all constraints, 1 is suitable and 0 is not suitable.

After the implementation of equation 1, the following sites with the different suitability values come up for the hospital location.

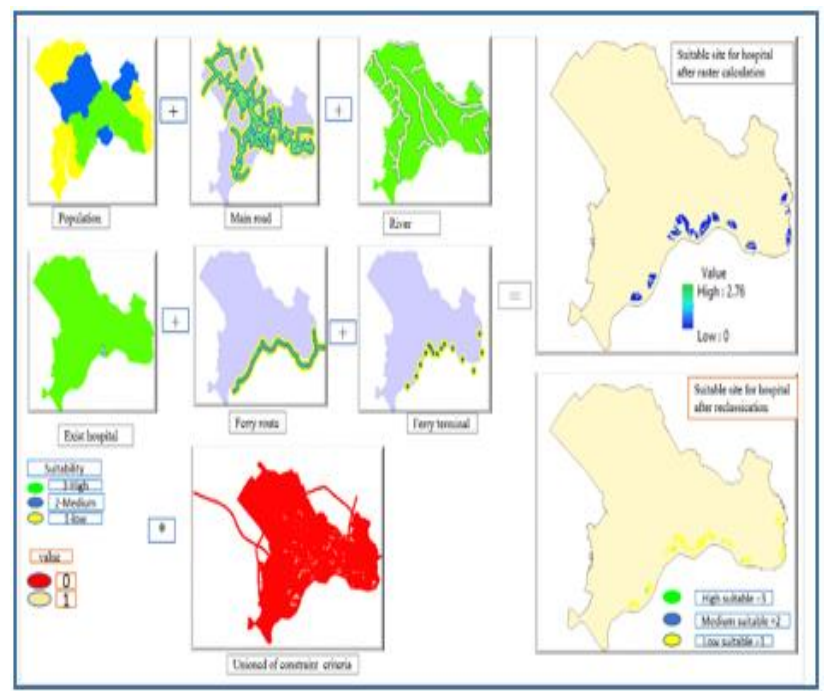

Fig. 6 Site selection result

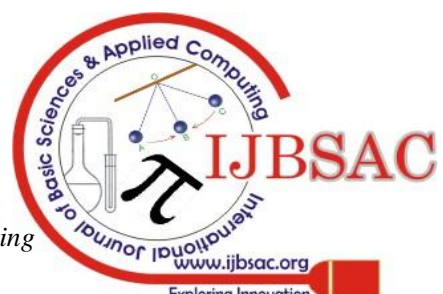




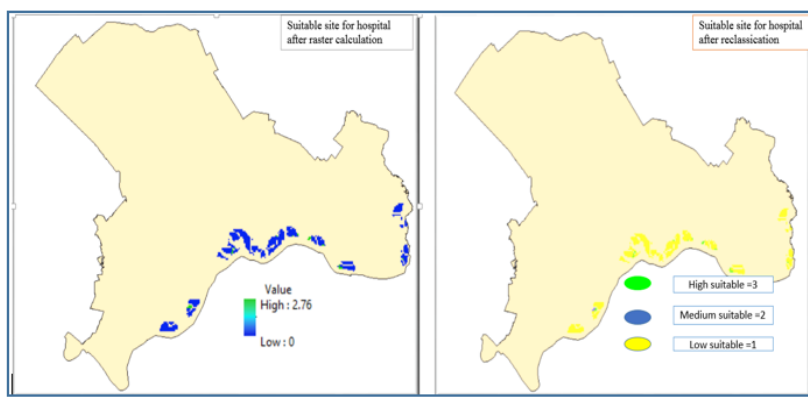

Fig. 7 Suitable sites for the new hospital

\section{SITE SELECTION FROM CANDIDATE SITES}

After the raster calculator, there are several sites with high suitability, medium suitability, and low suitability. There are 48 candidates' sites for the hospital, in order to have a specific site, firstly, the sites with low suitability and medium suitability excluded. (Fig. VIII).

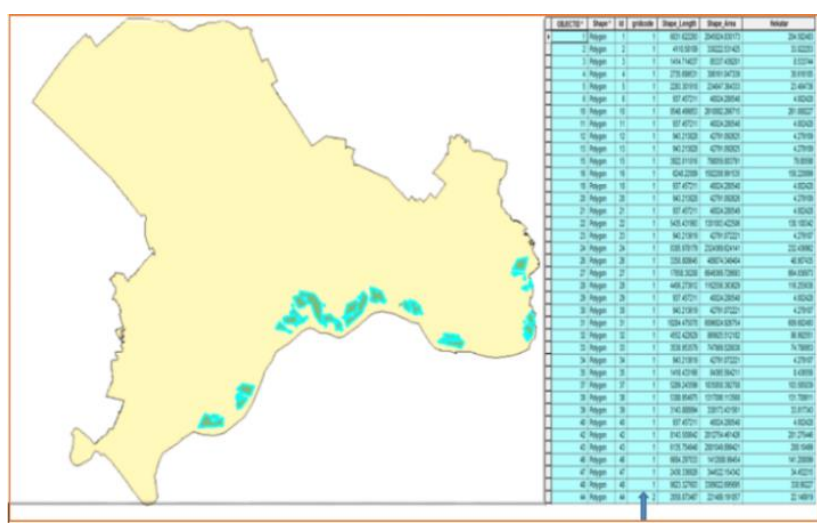

Fig. 8 Site with low and medium suitability

Sites with low suitability and medium suitability excluded from candidate sites, now 10 sites with high suitability are remaining. As in this research type B hospital for 200000-300000 population with 400- 600 beds considered, then the minimum area for this kind of hospital must be more than 12 Hectares. Therefore, the areas with less than 12 Hectares areas exclude from candidate's sites. (Fig IX).

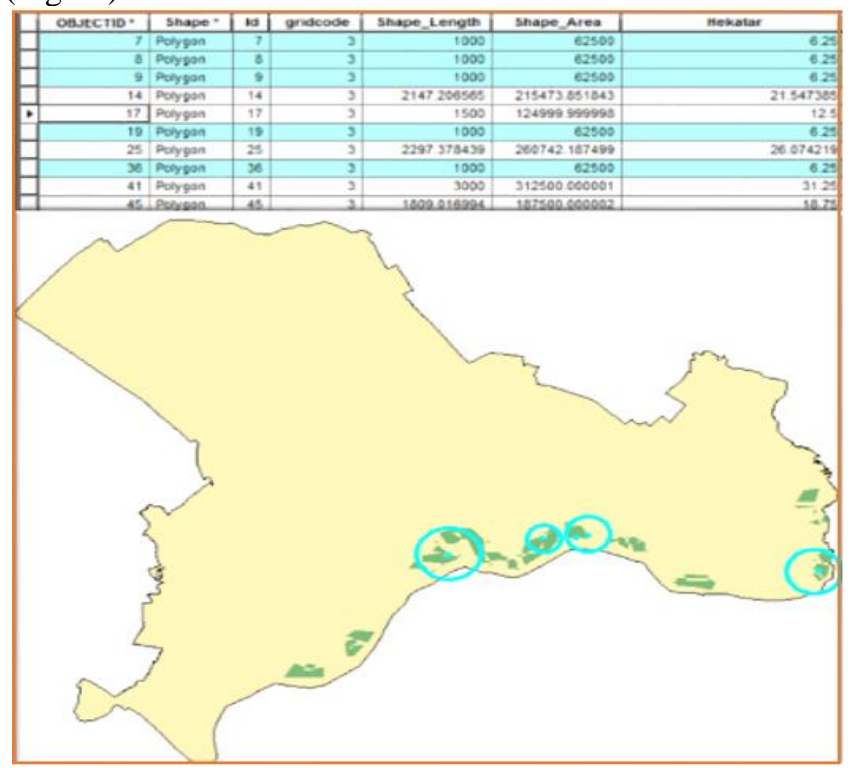

Fig. 9 Suitable sites with less than 12 Hectares
Now 5 suitable sites with more than 12 Hectares remain. Form these 5 areas the areas which located near to existing hospital have excluded. If these areas named as A, B, C, D, and $\mathrm{E}$ thus, site $\mathrm{D}$ and site $\mathrm{C}$ excluded due to being near to existing Hospital. Fig. X.

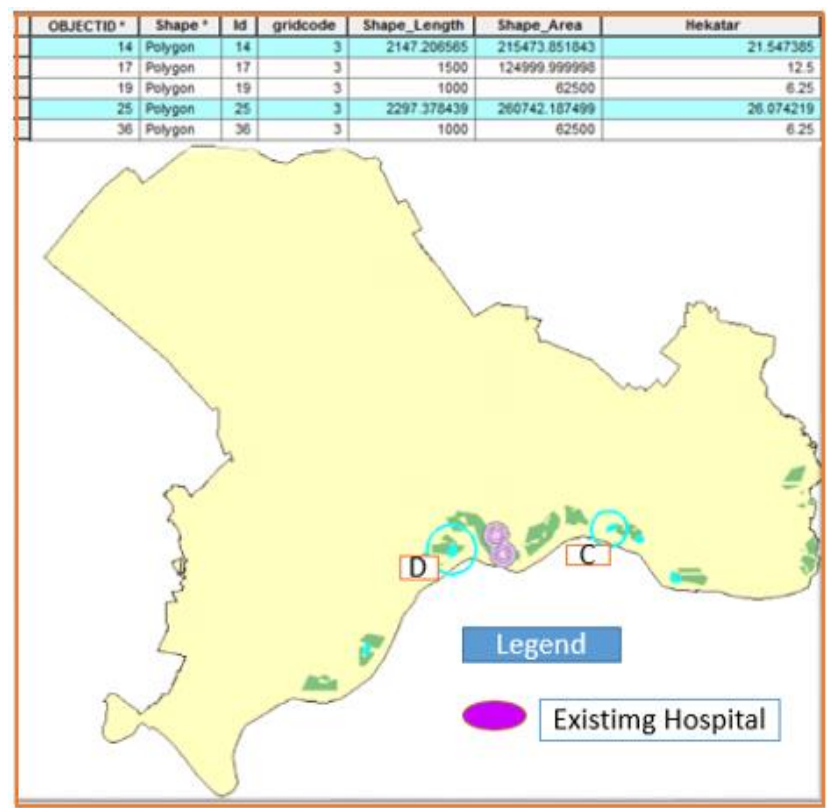

Fig. 10 The suitable site near to Exist hospital

From these three remaining sites the site A according to land use, located near to industrial areas. Because the industry and factory have negative impacts on patients thus, site A excluded from candidate sites. Fig. XI.

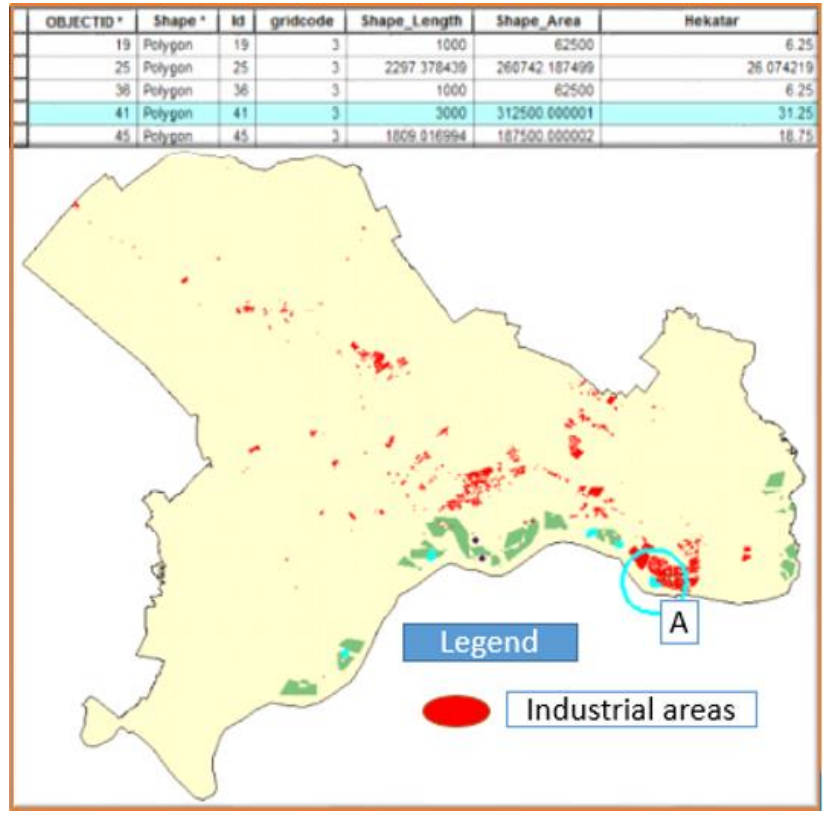

Fig. 11 The suitable site near to the industry

Site $\mathrm{E}$ is far from the residential areas it cannot ensure good accessibility. On the other hand, site E as well located near to agriculture areas. Therefore, this site excluded from candidate sites. Fig. XII.

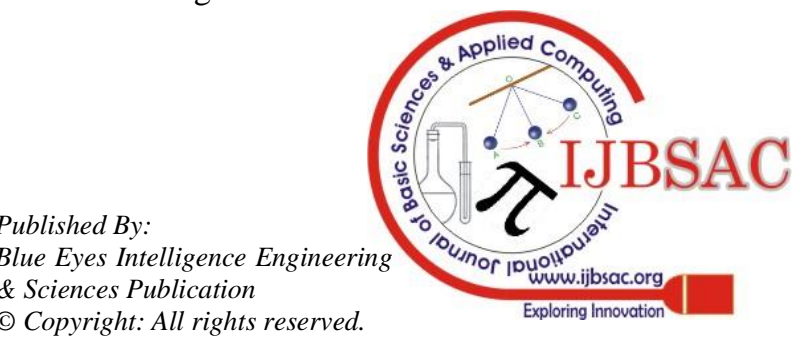




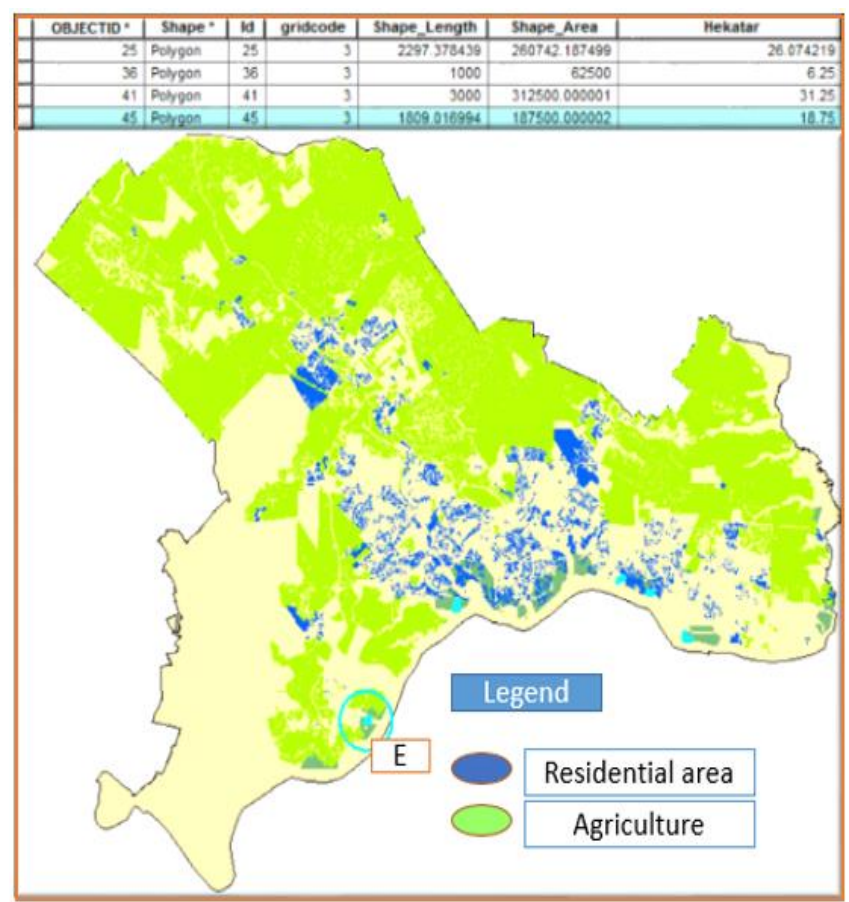

Fig. 12 The suitable site far from residential areas

Site B located near to the residential areas which can ensure accessibility. On the other hand, this site located further from existing hospital in contrast to site C and D. Furthermore, this site located further from factories in contrast to site A. In addition, this site located near to residential area and commercial areas in contrast to site E. Moreover, this site locates near to main road ferry-terminal and ferry route which ensure the accessibility. Therefore, this site is the most suitable site from candidate sites and has been chosen for site of hospital in Iskandar Malaysia. Fig. XIII. The site located in PasirGudang region, in the neighbor of Taman Rinting and Taman Megah Ria as well as besides to JB East Coast Road Network. Fig. XIV.

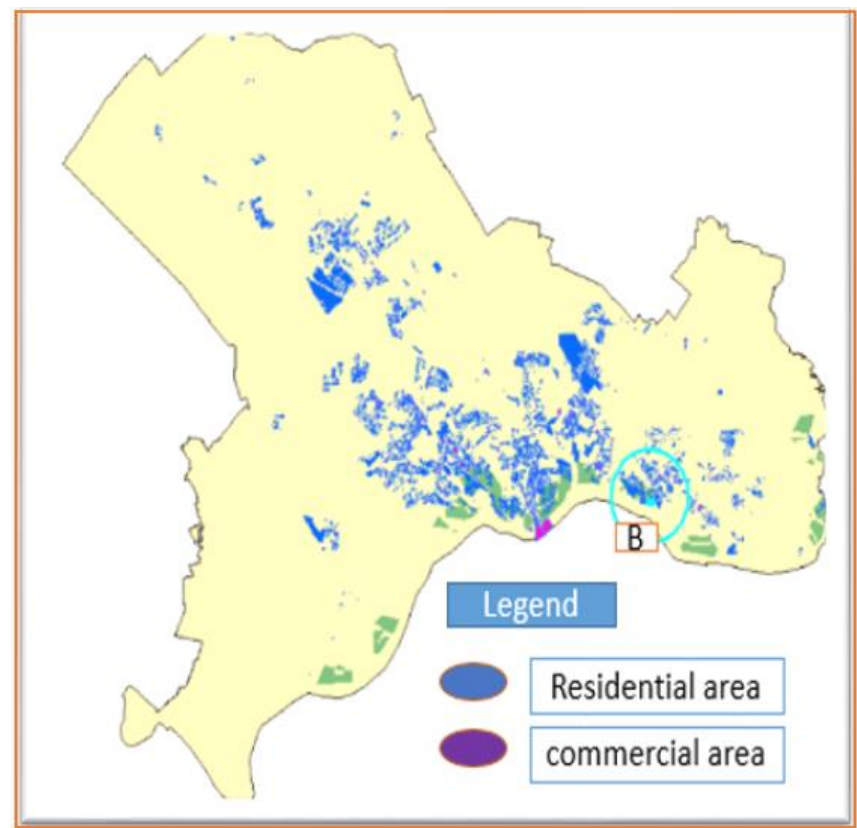

Fig. 13 The selected site for the hospital in Iskandar Malaysia
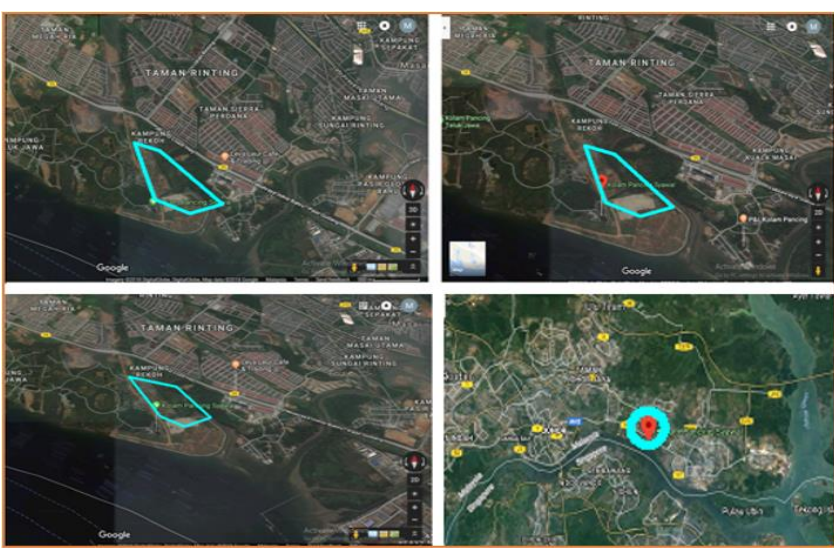

Fig. 14 Location of selected sites

\section{CONCLUSION}

GIS-based MCA provides a more technological, convenient and precise way for hospital site selection. It combines spatial and non-spatial data to construct visualized information that can be easily understood and analyzed by decision-makers. By combining the factor and constraint criteria, decision-makers can obtain very accurate solutions for problems. In this research, the optimal site for new hospitals allocated near to the main road, ferry route, ferryterminal, and high-density population areas which prove that the result from GIS method is accurate and practical.

\section{REFERENCES}

1. A. Soltani, and E. Z. Marandi. (2011). Hospital site selection using two-stages Fuzzy Multi-criteria decision making process. Journal of Urban and Environmental Engineering, 5(1), 32- 43.

2. L. Zhou, and J. Wu. (2012). GIS-Based Multi-criteria analysis for Hospital Site Selection in Haidian District of Beijing. One-year Master Thesis award. Department of Industrial Development, and land management, Hogskolan I Gavle, China.

3. D. Chatterjee, and B. Mukherjee. (2013). Potential Hospital Location Selection using AHP: A Study in Rural India. International Journal of Computer Applications, 71(17).

4. E. Triantaphyllou, and S.H. Mann. (1995). Using the analytical hierarchy process for decision making in engineering applications: some challenges. International Journal of Industrial Engineering: Applications and Practice, 2(1), 35-44.

5. H. Jordan, P. Roderick, D. Martin, and S. Barnett. (2004). Distance, rurality and the need for care: access to health services in South West England. International Journal of Health Geographics, 3(21), 1-9.

6. A. Mehrez, Z. Sinuany-Stern, T. Arad-Geva, and S. Binyamin. (1996). On the Implementation of Quantitative Facility Location Models: The Case of a Hospital in a Rural Region. The Journal of the Operational Research Society, 47(5), 612-625.

7. F. Rahimi, A. Goli, and R. Rezaee. (2017). Hospital locationallocation in Shiraz using Geographical Information System (GIS). Shiraz E-Med J, 18(8).

8. J. Mikaniki, H. Sadeghi. (2013). Location of medical-health centers in Birjand city through a combination of network analysis process (ANP) and paired comparisons by GIS. Environmental Based Territorial Planning, 15(9), 121-142.

9. N. S. Rabe, M. M. Osman, and S. Bachok. (2014). Economics of Local People: Iskandar, Malaysia. Procedia - Social and Behavioral Sciences, 153 (2014) 463- 478.

10. A. Rizzo and J. Glasson. (2012). City profile Iskandar Malaysia. Cities, 29 (2012) 417-427.

11. Iskandar Regional Development Authority (2013).Low Carbon Society Blueprint for Iskandar Malaysia 2025. Retrieved from https://www.nies.go.jp/unfccc_cop/2014/4.4.pdf.

12. Iskandar Regional Development Authority (2011). Transportation Blueprint 2010-2030 for Iskandar Malaysia. Retrieved from. iskandarmalaysia.com.my/downloads/Transportation-Blueprint.pdf.

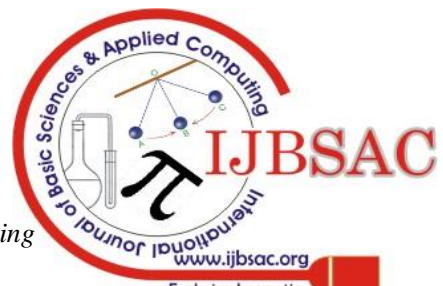




\section{AUTHORS PROFILE}

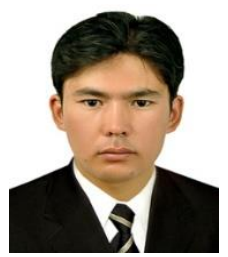

Maqsood Rezayee graduated fromKabul Polytechnic University in 2014 withBachelor of Science in Architecture Department Faculty of Construction. Following that he entered to an academic assessment and examination to be selected as an academic member of Nangarhar University and passed the assessment with the highest score. Then, in 2015 he accepted as full-time lecturer at the Department of Architecture, Faculty of Engineering at Nangarhar University, Afghanistan. After 2 years of teaching at the Architecture Department in 2017, he got an offer letter from UniversitiTeknologi Malaysia to study Master of Science (Urban and Regional Planning) in Faculty of Built Environment and Surveying, from which he graduated in 2019. After graduation from UniversitiTeknologi Malaysia, he is continuingfull-time lecturer position at the Department of Architecture, Faculty of Engineering at Nangarhar University, Afghanistan. 